\title{
Molecular markers for genetic diversity, gene flow and genetic population structure of freshwater mussel species
}

\author{
Choupina, $A B{ }^{a *}$ and Martins, $I M .^{b}$

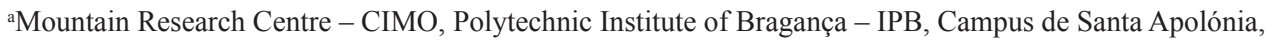 \\ Apartado 1172, 5301-855, Bragança, Portugal \\ ${ }^{\mathrm{b}}$ Centre of Biological Engineering - CEB, University of Minho, 4710-057, Braga, Portugal \\ *e-mail: albracho@ipb.pt
}

Received: November 26, 2012 - Accepted: May 20, 2013 - Distributed: November 30, 2014

\begin{abstract}
Freshwater mussel species are in global decline. Anthropogenic changes of river channels and the decrease of autochthonous fish population, the natural hosts of mussels larval stages (glochidia), are the main causes. Therefore, the conservation of mussel species depends not only on habitat conservation, but also on the availability of the fish host. In Portugal, information concerning most of the mussel species is remarkably scarce. One of the most known species, Unio pictorum is also in decline however, in the basins of the rivers Tua and Sabor (Northeast of Portugal), there is some indication of relatively large populations. The aforementioned rivers can be extremely important for this species conservation not only in Portugal, but also in the remaining Iberian Peninsula. Thus, it is important to obtain data concerning Unio pictorum bioecology (distribution, habitat requirements, population structure, genetic variability, reproductive cycle and recruitment rates), as well as the genetic variability and structure of the population. Concomitantly, information concerning fish population structure, the importance of the different fish species as "glochidia" hosts and their appropriate density to allow effective mussel recruitment, will also be assessed. The achieved data is crucial to obtain information to develop effective management measures in order to promote the conservation of this bivalve species, the conservation of autochthonous fish populations, and consequently the integrity of the river habitats.
\end{abstract}

Keywords: molecular markers, freshwater mussel, mtDNA, PCR.

\section{Marcadores moleculares para estudo da diversidade genética, fluxo génico e estrutura genética de populações de espécies de mexilhões de água doce}

\section{Resumo}

As espécies de mexilhões de água doce estão em declínio global. Mudanças antropogénicas do canal dos rios e diminuição das populações de peixes autóctones, os hospedeiros naturais do mexilhão nos estágios larvais (glochidia), são as principais causas. Portanto, a conservação de espécies de mexilhão depende não só da conservação dos habitats, mas também da disponibilidade do hospedeiro peixe. Em Portugal, a informação relativa à maioria das espécies de mexilhão é extremamente escassa. Uma das espécies mais conhecidas, Unio pictorum também está em declínio, no entanto, nas bacias dos rios Tua e Sabor (Nordeste de Portugal), existe indicação de populações relativamente grandes. Os rios acima mencionados podem ser extremamente importantes para a conservação das espécies, não só em Portugal, mas também na restante Península Ibérica. Assim, é importante obter dados relativos à bioecologia do Unio pictorum (distribuição, requisitos de habitat, estrutura populacional, variabilidade genética, ciclo reprodutivo e as taxas de recrutamento), bem como a variabilidade e estrutura genética da população. Concomitantemente, informações sobre a estrutura da população de peixes, a importância das diferentes espécies de peixes como hospedeiros e sua densidade adequada para permitir o recrutamento eficaz do mexilhão, também será avaliada. Os resultados obtidos serão cruciais para obter informações que permitam o desenvolvimento de medidas de gestão eficazes, a fim de promover a conservação destas espécies de bivalves, a conservação das populações de peixes autóctones e, consequentemente, a integridade dos habitats fluviais.

Palavras-chave: marcadores moleculares, mexilhão de água doce, mtDNA, PCR.

\section{Description}

In Portugal the available data concerning freshwater mussel species is extremely scarce (Nobre, 1941; Reis, 2003). Recently, Reis and co-workers focused only on

the abundance and population structure of the mussel Margaritifera margaritifera (Reis, 2003). Recent data of geographical distribution of bivalve species is being 
updated by the Portuguese Institute of Nature and Forest Conservation (ICNF). An international team (Araújo et al. in preparation), is also characterising the phylogeny of Unionidae in Portugal, Iberian Peninsula and Europe. Additionally, and mainly in the south of Portugal, some research is ongoing concerning: (1) The bioecology of Unio crassus in the south west of the Iberian Peninsula ( $\mathrm{J}$. M. Reis Ph.D. thesis IPM, FCUL, VirginiaTech); (2) The bioecology of Corbicula fluminea in Guadiana catchment (J. Teutónio Ph.D. thesis UAlg) and (3) on Anodonta cygnea physiology (J. Machado research team - ISCBA). Therefore, in Portugal, information concerning Unio pictorum bioecology is non-existent. Availability of polymorphic molecular markers is crucial to carry out population genetic studies. For the last decade, microsatellites have been the elected markers for population genetics studies because they are highly polimorphic, codominant, neutral and relatively easy to obtain. Among Unionidae species, this marker has been developed only for Lampsilis abrupta (Eackles and King, 2002). Therefore, development of microsatellite markers would be an important contribution. The use of molecular technology has become increasingly important in conservation biology (Queller et al., 1993; Hillis et al., 1996; Haig, 1998). The development of molecular markers within the mitochondrial DNA (mtDNA), and nuclear microsatellites have provided the potential for determining evolutionary relationships among individuals (Avise, 1992; Moritz, 1995; Georges and Adams, 1996), and are also useful to measure levels of gene flow and population structure (Hurwood and Hughes, 1998; Waters and Wallis, 2000). Genetic techniques have become part of a repertoire of tools, along with ecological and demographic techniques needed to address the increasing loss of biodiversity and must be included as an essential part of conservation efforts (Moritz, 1994a, b; Haig, 1998; Hedrick, 2001). The application of modern genetic techniques has become widespread in many studies, primarily due to several key advances in molecular technology that have greatly increased the impact of population genetics on biology (Hillis et al., 1996; Haig, 1998; McPherson and Møller, 2000; Sunnucks, 2000; Balloux and Lugon-Moulin, 2002). The most important developments have been the polymerase chain reaction (PCR), which amplifies specific stretches of DNA into useable concentrations, the application of evolutionarily conserved sets of PCR primers, the advent of hyper variable microsatellite loci and routine DNA sequencing in biological laboratories (Jarne and Lagoda, 1996; Palumbi, 1996; Goldstein and Schlotterer, 1999; Sunnucks, 2000). These innovations, coupled with the variety of statistical analyses and computer programs, have meant that much of the information inherent in molecular genetic data can be used (Sunnucks, 2000). The advent of the PCR has also greatly reduced the cost and simultaneously increased the ease of field studies (Steinberg and Jordan, 1998). For example, because PCR can work with a minimum or degraded template of DNA, it permits the non-destructive sampling of populations. Samples can be obtained from skin biopsies, individual hairs and scat. DNA can also be amplified from dried or preserved museum specimens (Queller et al., 1993; Mitton, 1994; Taylor et al., 1994; Moritz, 1994b). Most importantly, the analysis of genetic structure does not require tracking the fate of individuals, or even capturing individuals more than once (Steinberg and Jordan, 1998). These sampling methods mean that genetic data can be obtained from highly endangered species without sacrificing a single individual (Steinberg and Jordan, 1998). Typically, in a diploid organism, each individual can have one or two different states (alleles) per character (locus). Genetic markers reflect differences in DNA sequences and thus can be used in a variety of situations (Sunnucks, 2000). Three markers that have been used extensively in conservation genetics are allozymes, microsatellites and mtDNA. The analysis of mtDNA has been extensively used as a marker for population genetic studies and is a powerful tool in studies of gene flow and evolutionary biology (Norman et al., 1994; Moritz, 1994b; Chiarello, 1995). mtDNA is inherited maternally with no recombination, making this molecular marker more sensitive to the effects of population subdivision that result from small population sizes or barriers to gene flow (Wallis, 1994; Seddon et al., 1997). Studies of gene flow and evolutionary history in vertebrates have mostly used genetic markers found within the mtDNA genome, mainly because mutation rates vary in different regions of the mtDNA and areas can be selected which show high enough variation to distinguish divergence between populations (FitzSimmons et al., 1997). Additionally, because mtDNA is maternally inherited, all individuals typically possess only one type, hence there are effectively fewer copies of mtDNA than of nuclear genes in the population. This acts to increase the effects of genetic drift when population sizes are small. Processes such as genetic drift that alter the amount or distribution of variation will have a greater effect on the mtDNA, and in the absence of recombination the evolutionary history of the molecule is preserved, allowing the relationships among variants to be assessed with greater precision (Dodson et al., 1995). mtDNA sequence data have been widely applied to phylogenetic studies for such things as the examination of the varying divergence times of taxa and the investigation of the underlying biogeographic patterns in populations (Avise, 1994; Hurwood and Hughes, 1998). mtDNA phylogenies have provided information to help resolve taxonomic issues within species, for example the delineation of species boundaries within the Australian freshwater turtle family, Chelida (Georges and Adams, 1992, 1996; Georges et al., 2002). Although mtDNA is typically more sensitive than nuclear loci for detecting population subdivision (Dowling et al., 1990; Moritz et al., 1996), the use of these markers can be restricted to the history of female lineages within populations, and this is because mtDNA is maternally inherited in vertebrates (Moritz, 1994b; Avise, 1995; Haig, 1998). In contrast, nuclear markers provide information on gene flow that is the result of mating behavior by both males and females (FitzSimmons et al., 1997). To obtain a more accurate 
representation of the entire molecular history of an organism, a combination of mtDNA and nuclear markers can be used to identify a range of genetic events that occur in populations (Cronin, 1993; Moritz, 1994b).

\section{Development of Microsatellite Markers for the Freshwater Mussel}

Total DNA should be extracted from foot and adductor muscle tissue using a phenol-chloroform protocol and the sizes of DNA fragments should be analysed using agarose gel electrophoresis. Ribossomal RNA genes should be amplified by PCR and sequenced. The sequences of these genes should be compared with sequences deposited in EMBL or NCBI databases, for the confirmation of the species. Also, the mitochondrial gene - cytochrome c oxidase, should be amplified and sequenced. Amplification of the sequences of this gene should be compared among the different samples. Using appropriate bioinformatic tools, phylogenetic trees should be built. The sizes of DNA fragments produced by PCR amplification should be determined by agarose gel electrophoresis.

Recombinant clones from genomic libraries, containing microsatellites with flanking regions suitable for primer design, should be screened. After performing PCR to analyse microsatellite variability, the PCR products should be separated by electrophoresis on acrylamide:bisacrylamide gels on ALFespressII DNA Analyser and scored with ALLELELINKS 1.02 software. Genepop should be used to calculate allele frequencies, the expected and the observed heterozygosities (HE, Ho), to test for genotypic disequilibrium and to test for deficiency of heterozygotes (Fisher`s exact test.).

\section{Repercussions}

In fact, freshwater systems are losing biodiversity rapidly, yet little is known about the functional role of the species. Freshwater bivalves have an important role on river functioning. They influence the water quality by reducing suspended organic material. Considering that the integrity of the aquatic ecosystems is essential for water quality maintenance and for assuring human and wildlife needs (EU Directive 2000/60, 23 October), it is crucial to know the species bioecology in order to understand their role in the maintenance of ecosystem integrity. It would be interesting to obtain data that will promote the development of integrated management measures not only for Unio and autochthonous fish populations, but also for their habitats. From the social point of view, it is important to consider that the rivers are located in a region where the absence of industrial activity, concomitant with low profitability of agriculture, is gradually leading to human desertification. The implementation of new activities such as rural tourism and angling activities may constitute economic alternatives to local populations. However, to make those alternatives possible it is necessary to keep ecosystem integrity by promoting adequate management measures, allowing a sustainable development of this region. The promotion of those measures will only be possible with a deep knowledge of river ecosystem ecology. It is necessary to provide additional information at the population level that can be used to preserve local and regional genetic variation within the two river systems, which may otherwise be lost as a result of development. By increasing our understanding of the factors and processes that regulate biodiversity in freshwater river systems, it is hoped that future research will not only contribute to the knowledge on the ecology of a previously undescribed freshwater mussel species, but it will also assist in the management and conservation of freshwater river systems. Additionally, this information will provide a framework in which the conservation of vulnerable species can be factored into the development planning process, particularly as a result of habitat loss and modification due to water infrastructure development. The results will provide a genetic component that can be used in conjunction with the information above to help with the conservation and management of freshwater mussel species. Analysis of microsatellite loci could be used to assess genetic diversity and structure among and within populations. Concurrent research, using mtDNA analysis, could investigate historical relationships among the populations of freshwater mussel. These molecular markers are particularly useful for the measurement of genetic diversity, gene flow and genetic population structure.

\section{References}

AVISE, JC., 1992. Molecular population structure and he bibliographic history of a regional fauna: a case history with lessons for conservation biology. Oikos, vol. 63, no. 1, p. 62-76. http://dx.doi.org/10.2307/3545516.

AVISE, JC., 1994. Molecular markers, natural history, and evolution. New York: Chapman \& Hall. http://dx.doi.org/10.1007/978-14615-2381-9.

AVISE, JC., 1995. Mitochondrial DNA polymorphism and a connection between genetics and demography of relevance to conservation. Conservation Biology, vol. 7, p. 45-67.

BALLOUX, F. and LUGON-MOULIN, N., 2002. The estimation of population differentiation with microsatellite markers. Molecular Ecology, vol. 11, no. 2, p. 155-165. http://dx.doi.org/10.1046/j.09621083.2001.01436.x. PMid:11856418

CHIARELLO, AG., 1995. Density and habitat use of primates at an Atlantic forest reserve of southeastern Brazil. Revista Brasileira de Biologia = Brazilian Journal of Biology, vol. 55, no. 1, p. 105-110. PMid:7569145.

CRONIN, MA., 1993. Mitochondrial DNA in wildlife taxonomy and conservation biology: cautionary notes. Wildlife Society Bulletin, vol. 21, p. 339-348.

DODSON, JJ., COLOMBANI, F. and NG, PKL., 1995. Phylogeographic structure in mitochondrial DNA of a south-east Asian freshwater fish, Hemibagrus nemurus (Siluroidei; Bagridae) and Pleistocene sea-level changes on the Sunda shelf. Molecular Ecology, vol. 4, no. 3, p. 331-346. http://dx.doi.org/10.1111/j.1365294X.1995.tb00226.x.

DOWLING, TE., MORITZ, C. and PALMER, JD., 1990. Nucleic acids II: restriction site analysis Molecular systematics. In: 
HILLIS, DM. and MORITZ, C. (Eds.). Molecular Systematics. Sunderland: Sinauer Associates. p. 250-317.

EACKLES, MS. and KING, TL., 2002. Isolation and characterization of microsatellite loci in Lampsilis abrupta (Bivalvia: Unionidae) and cross-species amplication within the genus. Molecular Ecology Notes, vol. 2, no. 4, p. 559-562. http://dx.doi.org/10.1046/j.14718286.2002.00323.x.

FITZSIMMONS, NN., MORITZ, C., LIMPUS, CJ., POPE, L. and PRINCE, R., 1997. Geographic structure of mitochondrial and nuclear gene polymorphisms in Australian green turtle populations and male-biased gene flow. Genetics, vol. 147, no. 4, p. 1843-1854. PMid:9409840.

GEORGES, A. and ADAMS, M., 1992. A phylogeny for Australian chelid turtles based on allozyme electrophoresis. Australian Journal of Zoology, vol. 40, no. 5, p. 453-476. http://dx.doi. org/10.1071/ZO9920453.

GEORGES, A. and ADAMS, M., 1996. Electrophoretic delineation of species boundaries within the short-necked freshwater turtles of Australia (Testudines: Chelidae). Zoological Journal of the Linnean Society, vol. 118, no. 3, p. 241-260. http://dx.doi. org/10.1111/j.1096-3642.1996.tb01266.x.

GEORGES, A., ADAMS, M. and MCCORD, W., 2002. Electrophoretic delineation of species boundaries within the genus Chelodina (Testudines: Chelidae) of Australia, New Guinea and Indonesia. Zoological Journal of the Linnean Society, vol. 134, no. 4, p. 401-421. http://dx.doi.org/10.1046/j.1096-3642.2002.00007.x.

GOLDSTEIN, D. and SCHLOTTERER, C., 1999. Microsatellites: Evolution and applications. Oxford: Oxford University Press.

HAIG, D., 1998. Genomic imprinting. American Journal of Human Biology, vol. 10, no. 5, p. 679-680. http://dx.doi.org/10.1002/ (SICI)1520-6300(1998)10:5<679::AID-AJHB14>3.0.CO;2-5.

HEDRICK, PW., 2001. Conservation genetics: where are we now? Trends in Ecology \& Evolution, vol. 16, no. 11, p. 629-636. http://dx.doi.org/10.1016/S0169-5347(01)02282-0.

HILLIS, DM., MORITZ, C., and MABLE, BK. 1996. Molecular Systematics Sunderland. Sunderland: Sinauer Associates.

HURWOOD, DA. and HUGHES, JM., 1998. Phylogeography of the freshwater fish, Mogurnda adspersa, in streams of northeastern Queensland, Australia: evidence for altered drainage patterns. Molecular Ecology, vol. 7, no. 11, p. 1507-1517. http://dx.doi. org/10.1046/j.1365-294x.1998.00469.x. PMid:9819905

JARNE, P. and LAGODA, PJ., 1996. Microsatellites, from molecules to populations and back. Trends in Ecology \& Evolution, vol. 11 , no. 10 , p. 424-429. http://dx.doi.org/10.1016/01695347(96)10049-5. PMid:21237902

MCPHERSON, J. and MØLLER, SG., 2000. PCR: Basics from Background to Bench. Heidelberg: Springer-Verlag.

MITTON, JB., 1994. Molecular approaches to population biology. Annual Review of Ecology and Systematics, vol. 25, no. 1, p. 45-69. http://dx.doi.org/10.1146/annurev.es.25.110194.000401.

MORITZ, C., 1994a. Defining 'Evolutionarily Significant Units' for conservation. Trends in Ecology \& Evolution, vol. 9, no. 10, p. 373-375. http://dx.doi.org/10.1016/0169-5347(94)90057-4. PMid:21236896

MORITZ, C., 1994b. Applications of mitochondrial DNA analysis in conservation: critical review. Molecular Ecology, vol. 3, no. 4, p. 401-411. http://dx.doi.org/10.1111/j.1365-294X.1994.tb00080.x.
MORITZ, C., 1995. Uses of molecular phylogenies for conservation. Philosophical Transactions of the Royal Society of London, vol. 349, no. 1327, p. 113-118. http://dx.doi.org/10.1098/rstb.1995.0097.

MORITZ, C., WORTHINGTON-WILMER, J., POPE, L., SHERWIN, WB., TAYLOR, AC. and LIMPUS, CJ., 1996. Applications of genetics to the conservation and management of Australian fauna: Four case studies from Queensland. In SMITH, TB. and WAYNE, RK. (Eds.). Molecular Genetic Approaches in Conservation. Oxford: Oxford Univ. Press. p. 442-456.

NOBRE, A., 1941. Fauna malacológica de Portugal II. Moluscos terrestres e fluviais. Memórias e Estudos do Museu Zoológico, vol. 9, no. 124, p. 1-279.

NORMAN, JA., MORITZ, C. and LIMPUS, CJ., 1994. Mitochondrial DNA control region polymorphisms: genetic markers for ecological studies of marine turtles. Molecular Ecology, vol. 3, no. 4, p. 363-373. http://dx.doi.org/10.1111/j.1365-294X.1994. tb00076.x. PMid:7921361

PALUMBI, SR., 1996. Nucleic acids II: the polymerase chain reaction. In: HILLS, DM., MORTIZ, C. and MABLE, BK. (Eds.). Molecular System-atics. Sunderland: Sinauer Associates. p. 205-247.

QUELLER, DC., STRASSMANN, JE. and HUGHES, CR., 1993. Microsatellites and kinship. Trends in Ecology \& Evolution, vol. 8, no. 8, p. 285-288. http://dx.doi.org/10.1016/0169-5347(93)90256-O. PMid:21236170

REIS, J., 2003. The freshwater pearl mussel [Margaritifera margaritifera (L.)] (Bivalvia, Unionoida) rediscovered in Portugal and threats to its survival. Biological Conservation, vol. 114, no. 3, p. 447-452. http://dx.doi.org/10.1016/S0006-3207(03)00086-7.

SEDDON, JM., GEORGES, A., BAVERSTOCK, PR. and MCCORD, W., 1997. Phylogenetic relationships of chelid turtles (Pleurodira: Chelidae) based on mitochondrial 12S rRNA gene sequence variation. Molecular Phylogenetics and Evolution, vol. 7, no. 1, p. 55-61. http://dx.doi.org/10.1006/mpev.1996.0372. PMid:9007020

STEINBERG, EK. and JORDAN, CE., 1998. Using molecular genetics to learn about the ecology of threatened species: The allure and the illusion of measuring genetic structure in natural populations. In: FIEDLER, PL. and KAREIVA, PM. (Eds.). Conservation Biology. 2nd ed. New York: Chapman \& Hall. p. $440-460$

SUNNUCKS, P., 2000. Efficient genetic markers for population biology. Trends in Ecology \& Evolution, vol. 15, no. 5, p. 199-203. http://dx.doi.org/10.1016/S0169-5347(00)01825-5. PMid:10782134

TAYLOR, AC., SHERWIN, WB. and WAYNE, RK., 1994. Genetic variation of microsatellite loci in a bottlenecked species: the northern hairy-nosed wombat Lasiorhinus krefftii. Molecular Ecology, vol. 3, no. 4, p. 277-290. http://dx.doi.org/10.1111/j.1365294X.1994.tb00068.x. PMid:7921355

WALLIS, GP., 1994. Population genetics and conservation in New Zealand: a hierarchical synthesis and recommendations for the 1990s. Journal of the Royal Society of New Zealand, vol. 24, no. 2, p. 143-160. http://dx.doi.org/10.1080/03014223.1994.9517461.

WATERS, JM. and WALLIS, GP., 2000. Across the Southern Alps by river capture? Freshwater fish phylogeography in South Island, New Zealand. Molecular Ecology, vol. 9, no. 10, p. 1577-1582. http://dx.doi.org/10.1046/j.1365-294x.2000.01035.x. PMid:11050552 